\title{
The Development of Interactive Multimedia Mobile Learning about Bacterial Topic to train the Students' Ability of Science Literacy
}

\author{
Merinda Oktaviana a, ${ }^{\text {*, }}$, Murni Sapta Sari ${ }^{\text {b }}$, Sunarmi ${ }^{\text {c }}$ \\ ${ }^{1,2,3}$ Departement of Biology, Faculty of Mathematics and Natural Science, \\ Universitas Negeri Malang \\ Malang, Semarang Street, No. 5 Malang, Indonesia \\ *Corressponding author: oktavianamerindal@gmail.com
}

\begin{abstract}
Science literacy is a human's ability to understand science and use that understanding to be applied in solving a problem in everyday life. Students' science literacy skills are low due to the student's response in answering a question to explain the phenomenon has not fulfilled the aspects of science literacy. This research aims to develop an interactive multimedia Mobile Learning that is valid, practical, and effective in making students practice their science literacy skills. Interactive multimedia research and development of the Mobile Learning model uses a Research and Development model that adapts the development model of William W. Lee and Diana L. Owens. The stages of development in the model of Lee and Owens are (1) Assessment/Analysis, (2) Design, (3) Development, (4) Implementation, and (5) Evaluation. The results of this research and development obtained $97.8 \%$ validation value of media experts, obtained a validation value of $100 \%$ by topic experts, also earned an average of $94 \%$ value in the validation of expert assessment. So that based on the data results of this development research was very valid category the field-test results of research and development conducted with the researchers as a teacher for two meetings produced a practical test value by students of $84.42 \%$, a very practicable category. The practicality test results (field practitioner) obtained a value of $100 \%$, which was a very practical category. The value of effectiveness test in this study obtained an $\mathrm{N}$-gain value of 16.74 , which belonged to the low category (low effective).
\end{abstract}

\section{Introduction}

According to PISA, science literacy is a competency that can be called the ability to include science issues related to science ideas such as depicting reflective citizens. Based on OECD (1) a person who has a science literacy skills will be able to be engaged in a reasoned discourse about science and 
technology that can explain the phenomenon scientifically, evaluate and design scientific investigations, and interpret the data and facts scientifically. Indonesia's rank of a survey that was conducted by the Program for International Student Assessment (PISA) in 2012 was 64 of 65 countries in rank, with a score of 382 in the science category (2). In 2015 it was ranked at 64 of 72 with a score of 403 on the Science category(3), and in 2018 was ranked 74 of 79 with a score 396 on the science category(4) According to those data, Indonesian students are considered having very low science literacy.

Based on the observation that has been done in the internship activity (or commonly called as Kajian Praktik Lapangan in Indonesian context) on August to September 2019 starting on 29 July-9 September 2019 precisely at SMA Negeri 4 Malang, it was known that students' ability of science literacy was still low. Low understanding in science literacy is influenced by several factors, one of which is the learning media. Multimedia is instrumental in the development of learning that contributes to students' science literacy improvement (5). El-Mouelhy, et al., Android tablets in learning can improve the students' understanding of the topic. Mobile Learning is a solution in learning that puts aspects of ease and practicality and can be used anywhere and anytime(6). The use of Mobile Learning to improve science literacy skills is ineffective when it is not supported by adopting a learning model that bridges the development of science literacy skills. One of the learning models that allow students to actively develop a concept understanding by combining knowledge with reasoned skills and thinking is inquiry learning(7).

Based on the need analysis through interviews with teachers, it was found that the topic about bacteria was quite difficult so that it needed to require a medium that could visualize the topic for better learning implementation. Based on the background outlined, the study of bacterial topic in class X SMAN 4 Malang needed to be done with the development of interactive multimedia Mobile Learning that integrated model of guided inquiry and aspects of science literacy. This research aims to develop Mobile Learning as an interactive multimedia that is valid, practical, and effective in teaching science literacy skills of grade X students of SMA Negeri 4 Malang..

\section{Method}

This research design is development research. The study was conducted on January to February 2020. The development model in this study was adapted from the development model of William W. Lee and Diana L. Owens (8) consisting of five stages, which are (1) Assessment/Analysis, (2) Design, (3) Development, (4) Implementation and (5) Evaluation. The detailed stages of this study can be seen in Table 1 and the test subject of this study is in Table 2. 
Table 1.

Summary of the stages of development Model William W. Lee and Diana L. Owens

\begin{tabular}{|c|c|}
\hline Stage & Sub Stage \\
\hline \multirow[t]{2}{*}{ Assessment/ analysis } & 1. Research needs \\
\hline & 2. Thorough analysis \\
\hline \multirow[t]{5}{*}{ Design } & 1. Arranging a schedule for development activity \\
\hline & 2. Team Projects \\
\hline & 3. Media Specifications \\
\hline & 4. Content structure \\
\hline & 5. Control configuration \\
\hline Development and & 1. Developing project-computer based \\
\hline \multirow[t]{3}{*}{ Implementation } & 2. Developing the Web and determining the Internet that \\
\hline & helps the learning environment \\
\hline & 3. Developing products into the environment \\
\hline \multirow[t]{6}{*}{ Evaluation } & 1. Evaluation objectives \\
\hline & 2. Evaluation strategy \\
\hline & 3. Evaluation plan \\
\hline & 4. Validity measurement \\
\hline & 5. Developing instruments \\
\hline & 6. Collecting and analyzing data \\
\hline
\end{tabular}

(Adapted from Lee \& Owens, 2004:3)

Table 2.

Test subject criteria

\begin{tabular}{|c|c|c|c|}
\hline $\begin{array}{c}\text { Validator/Practitioner/ } \\
\text { Object }\end{array}$ & Profession & $\begin{array}{l}\text { Number } \\
\text { (people) }\end{array}$ & Criteria \\
\hline Media experts & $\begin{array}{l}\text { Biology } \\
\text { lecturer }\end{array}$ & 1 & $\begin{array}{l}\text { 1. Mastered in media learning } \\
\text { courses } \\
\text { 2. studied at least S-2 degree in } \\
\text { biology or biology education }\end{array}$ \\
\hline Topic experts & $\begin{array}{l}\text { Biology } \\
\text { lecturer }\end{array}$ & 1 & $\begin{array}{l}\text { 1. Mastered in microbiology courses } \\
\text { for more than five years } \\
\text { 2. Minimum educated S-2 biology or } \\
\text { biology education }\end{array}$ \\
\hline
\end{tabular}




\begin{tabular}{|c|c|c|c|}
\hline $\begin{array}{c}\text { Validator/Practitioner/ } \\
\text { Object }\end{array}$ & Profession & $\begin{array}{l}\text { Number } \\
\text { (people) }\end{array}$ & Criteria \\
\hline Assessment experts & $\begin{array}{l}\text { Biology } \\
\text { lecturer }\end{array}$ & 1 & $\begin{array}{l}\text { 1. Having experience in the course of } \\
\text { study assessment and evaluation } \\
\text { for more than five years. } \\
\text { 2. Studied at least S-2 biology or } \\
\text { biology education }\end{array}$ \\
\hline Field Practitioner & $\begin{array}{l}\text { Biology } \\
\text { teacher }\end{array}$ & 1 & $\begin{array}{l}\text { 1. Teacher of biology subjects in } \\
\text { class } \mathrm{X} \\
\text { 2. Have a minimum academic } \\
\text { degree S1 on biology education }\end{array}$ \\
\hline Subject of trial & Student & 31 & Class X at SMA Negeri 4 Malang \\
\hline
\end{tabular}

The types of data in this development study were quantitative and qualitative data. Quantitative Data was obtained from the validity measurement of the multimedia interactive mobile learning of bacterial topic by media experts, topic experts, assessment experts, teacher and students' responses also students' pre-test and post-test scores. Comments, suggestions took qualitative Data, and field practitioners as a revision reference to generate mobile interactive multimedia learning with good eligibility criteria for the learning process.

Instruments that were used in the validation of multimedia interactive Mobile learning about bacterial topic in the form of a validation questionnaire, teacher's and students' response questionnaires, and a test of effectiveness in the form of questions-science literacy based problem. Quantitative data analysis techniques of the validity results and practicality test used the following formula.

$$
\mathrm{NPr}=\frac{T S-e}{T S-\max } \times 100 \%
$$

Description:

NPr : score Percentage value (\%)

TS-e : number of scores written by the respondent in one question item

TS-max : maximum score Amount

Source $\quad:(9)$ 
The effectiveness of interactive multimedia mobile learning is achieved through pre-test results and post-tests on student learning outcomes after being analyzed using the $\mathrm{N}$-gain formula.

$$
\mathrm{N}-\text { Gain }=\frac{\text { Posttest Scores }- \text { Pretest Scores }}{\text { Maximum Scores-Pretest scores }} \times 100
$$

\section{Results}

The results of interactive multimedia validation of mobile learning about bacterial topics by media experts, topic experts, and assessment experts can be seen in Table 3 and the Mobile Learning Interactive Multimedia design view can be seen in Figure 1.

Table 3.

Validation result

\begin{tabular}{ll}
\hline Expert Validators & Result $(\boldsymbol{\%})$ \\
\hline Media Expert & 97.8 \\
Topic Expert & 100 \\
Assessment Expert & 94 \\
\hline
\end{tabular}

The result data of practically test by the teacher got $100 \%$ value based on the questionnaire that had been filled by the teacher showed that the media was categorized as very practical to use. The result data of practicality test by students gained $84.42 \%$ value based on the student's questionnaire. This showed that the media was categorized as very practical to use. The effectiveness test was conducted through the pre-test and post-test, then it was acquired $\mathrm{N}$-gain value with 16.74 , which was categorized as the low category (low effectivity). Then the increase of pre-test and post-test results to train science literacy skills of 31students at X MIPA class SMA Negeri 4 Malang was still in the low category. 


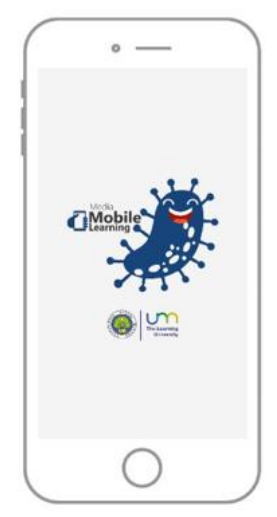

(a)

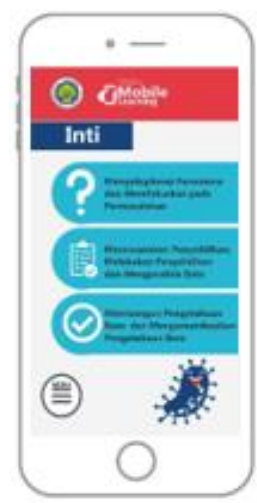

(d)

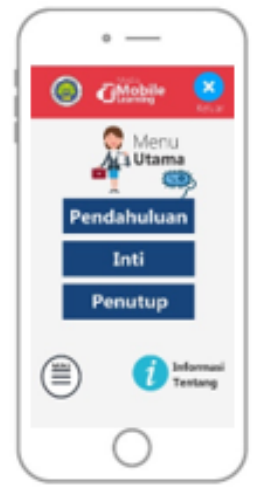

(b)
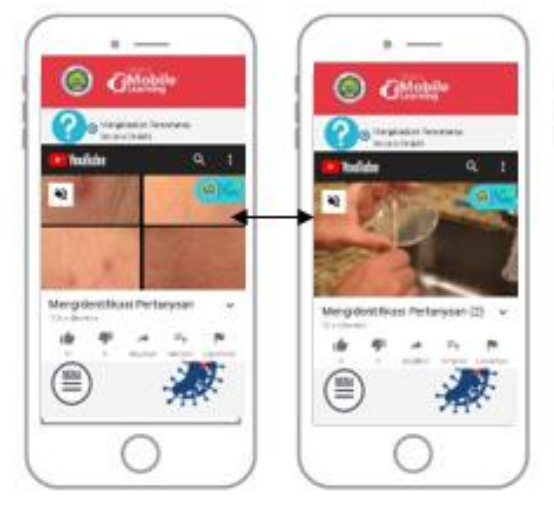

(e)

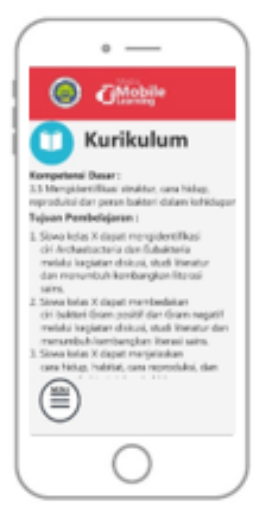

(c)

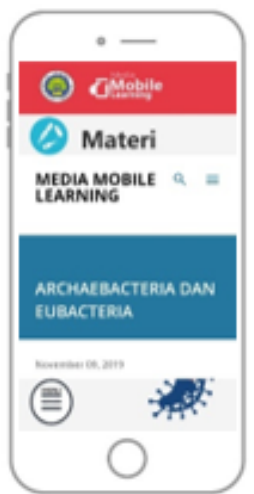

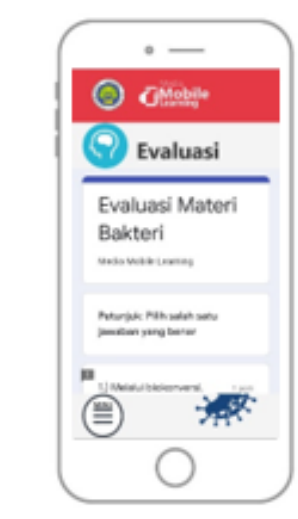

(f)

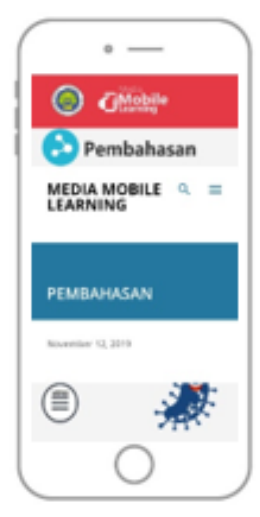

(g)

Figure 1. Mobile Learning Interactive Multimedia design view (a) Splash screen, (b) Main menu,

(c) The curriculum (basic competencies and learning objectives), (d) Interactive multimedia Mobile Learning that integrated model of guided inquiry (e) materials (text, images, videos), (f) Exercise problems, (g) Discussion

\section{Discussion}

Mobile Learning Interactive Multimedia is an application that attracts the students' interest to follow the learning process and it helps students in learning according to students' wishes, which is getting more fun learning. According to the research results, Surahman \& Surjono (10) stated that 
learning by using mobile learning media makes students interested and enjoy learning. The learning process will be effective when students are happy and in good condition.

Interactive Multimedia Mobile Learning has been developed to support materials in the learning process such as the curriculum (basic competencies and learning objectives), materials (text, images, videos), exercise problems, and discussion. The topic that consists of this Mobile Learning Interactive Multimedia is based on the basic competency of 3.5 and 4.5 which is about bacteria.

This research \& development has been tested for the validity, practicality and effectiveness testing outlined in the following explanations.

\section{a. Validity Test}

Validation is a measurement to validate the instruments. Validation is an important process in a study to know if instruments are able to measure what should be measured. The processes of expert validation are done by media experts, topicl experts, and assessment experts.

\section{Media experts}

Analysis results based on the media experts' assessments gave the score of $97.8 \%$, which was a very valid category. A medium was considered very valid. The general element presented in Mobile Learning Interactive multimedia was very worthy to be used in the learning process (11). Several components needed to be repaired which were about layout of mobile learning multimedia. Some of the buttons in the application were too large and the text on the buttons had a size that was similar and synchronous, so it will reduce the visual's attractiveness of the application. Some of these components needed to be repaired because media learning plays an important role in understanding the learning topics(12).

\section{Topic Expert}

The analysis results based on the assessments that were given by the topic experts were the score of $100 \%$, which was in a very valid category meaning those materials in multimedia has been very appropriate to the level of students' knowledge and has been referring to the demands of the basic competence 3.5 and 4.5 about the bacteria topic correctly. Several components on bacteria topic need to be improved, especially about the unit of bacteria measurement, the addition of material sources that were still unclear, and the less appropriate terms, so they need for correction and improvement. Media learning should prioritize clarity and mastery of the topic so that the materials that were presented on the media were complete and clear(13).

\section{Assessment Expert}

The analysis results based on the assessment experts' assessments stated that the average value was $94 \%$, which was considered a very valid category. Based on the average percentage, it was known that the Science Literacy instrument that had been developed has very valid criteria in the field of the questions provision in the form of multiple-choice and description, material realm, construction, and 
language(14). Following this percentage, it can be said that the science literacy instruments that had been developed in terms of content validity were appropriate and related to the topic. Science literacy instruments also had fulfilled the construct validity, which was already in accordance with the competency indicators and the indicators of science literacy rate of PISA level 1a, 1b up to Level 6. Each level of science literacy was integrated with one or several basic competence achievement indicators.

\section{b. Practicality Test}

The Practical Testing of Mobile Learning interactive multimedia was conducted to determine the practicality of product use in terms of the ease of operating and the attractiveness of the product through the response on students' and teachers' questionnaires. The practicality testing results showed that the practicality of the product was in a very practical category. This category showed that mobile learning interactive multimedia was considered attractive and easy to use in the learning process, it was following El-Mouelhy, et al., (15) who concluded that the use of Android tablets in learning was able to improve the students' understanding of the topic. The use of Mobile Learning was a solution in learning that put aspects of ease, practicality and could be used anywhere and anytime(6). Aspects of Science Literacy in Mobile Learning Interactive multimedia that had been developed also played a role in training student literacy skills. Latip \& Permanasari (16) stated that the use of multimediabased science literacy provided a role in enhancing students science literacy.

\section{c. Effectiveness Test}

The Effectiveness testing of students' science literacy skills generated score in low category (low effective). It showed that the mobile learning interactive multimedia that had been developed was capable of enhancing students ' science literacy skills, but did not provide high effectiveness. Studying the role of bacteria or biological phenomena that related to it required epistemic knowledge.

Epistemic knowledge is a competency in evaluating and designing scientific investigations, interpreting data and evidence scientifically. This competence requires more than known knowledge, epistemic knowledge relies on the understanding of how scientific knowledge is constructed and holds the level of scientific knowledge(17) so that Mobile Learning interactive multimedia itself is not able enough to improve science literacy skills in high improvement. The lack of students' epistemic knowledge on bacterial topic caused the use of interactive Mobile Learning was in low effectiveness level.

The short implementation process of interactive multimedia mobile learning also affects the low effectiveness of interactive multimedia mobile learning. So, the implementation process has not made students accustomed to conducting experiments. 


\section{Conclusion}

The Mobile learning Interactive Multimedia consisting of bacteria topics had a value of $97.8 \%$ on the validation by media experts which was in a very valid category. It obtained a value of $100 \%$ on the validation by a topic expert who was considered as very valid categories. It earned an average of 94\% value in the validation of expert assessment which was in a very valid category. The field-test results of research and development conducted by the researcher who was as a teacher for two meetings produced a practical test value of students with $84.42 \%$ which was in a very practicable category. The practicality testing results by the Teacher (field practitioner) obtained a value of 100\%, which was in a very practical category. The value of effectiveness testing in this study obtained an $\mathrm{N}$-gain value of 16.74 , which belonged to the low category (low effective).

\section{References}

[1] OECD. PISA 2015 assessment and analytical framework: Science, reading, mathematic, financial literacy and collaborative problem solving. OECD Publishing; 2017.

[2] OECD. PISA 2012 results in focus: What 15-year-olds know and what they can do with what they know. Vol. I. Paris, France; 2013.

[3] OECD. PISA 2015 RESULTS: Excellence and Equity in Education. Vol. I. OECD; 2017.

[4] OECD. PISA 2018 Results (Volume I): What Students Know and Can Do. PISA, editor. Vol. I. Paris: OECD Publishing; 2019.

[5] Fan X, Geelan D. Integrating Information Technology and Science Education For The Furute : A Theoretical Review On The Educational Use of Interactive Simulations. Proc 2012 Aust Comput Educ Conf. 2012;2-5.

[6] Aripin I. Konsep dan Aplikasi Mobile Learning dalam Pembelajaran Biologi. J Bio Educ. 2018;3(April):1-9.

[7] Listianingrum N, Maridi, Aminah NS. Pengembangan Perangkat Pembelajaran IPA Menggunakan Model Inkuiri Terbimbing Berbasis Literasi Sains untuk Memberdayakan Ketrampilan Proses Sains. Pros SNPS (Seminar Nas Pendidik Sains). 2017;21:178-86.

[8] Lee WW, Owens DL. Multimedia-based instructional design: computer-based training, webbased training, distance broadcast training, performance-based solutions. 2nd ed. Taff R, editor. San Francisco: Pfeiffer; 2004.

[9] Akbar S. Instrumen Perangkat Pembelajaran. Bandung: Rosdakarya; 2013.

[10] Surahman E, Surjono HD. Pengembangan adaptive mobile learning pada mata pelajaran biologi SMA sebagai upaya mendukung proses blended learning. J Inov Teknol Pendidik. 2017;4(1):26-37. 
[11] Rasyid M, Azis AA, Saleh AR. Pengembangan Media Pembelajaran Berbasis Multimedia dalam Konsep Sistem Indera pada Siswa Kelas XI SMA. J Pendidik Biol. 7(2):69-80.

[12] Nurhayatin T, Marlia, Fauziyah DF. Kelayakan E-Comics Portable Bahasa Indonesia Kelas Viii Berdasarkan Analisis Validasi Ahli. Semantik. 2018;7(1):114-24.

[13] Pratiwi EI, Yeni LF, Wahyuni ES. Pembuatan Video Teknik Isolasi dan Karakterisasi Bakteri Asam Laktat Pekasam Ikan Kembung Kelas X. J Pendidik dan Pembelajaran Khatulistiwa. 2015;4(5).

[14] Novanti SKE, Yulianti E, Mustikasari VR. Pengembangan Instrumen Tes Literasi Sains Siswa SMP Materi Tekanan Zat dan Penerapannya dalam Kehidupan Sehari-hari. J Pembelajaran Sains. 2018;2(2):6-12.

[15] El-mouelhy I, Hin I, Poon C, Na A, Hui N, Sue-chan C. Does a Creative Learning Medium Matter? Impact of Low Cost Android Tablets on Elementary Students ' English Comprehension, Perceived Performance and Memory Retention. 2013;4(12):42-50.

[16] Latip A, Permanasari A. Pengembangan Multimedia Pembelajaran Berbasis Literasi Sains Untuk Siswa SMP Pada Tema Teknologi. Edusains. 2015;7(2):160-71.

[17] Fardan A, Rahayu S, Yahmin. Kajian Penanaman Pengetahuan Epistemik Secara Eksplisit Reflektif pada Pembelajaran Kimia dalam Meningkatkan Literasi Sains Siswa SMA. Pros Semnas Pend IPA Pascasarj UM. 2016;1:529-41. 